https://doi.org/10.17816/MAJ191S1161-162

\title{
ANTIMICROBIAL ACTIVITY OF LYSOZYME TOWARDS LISTERIA MONOCYTOGENES AT VARIOUS MEDIUM CONDITIONS
}

\author{
M.N. Berlov', S.V. Legkovoy ${ }^{2}$, E.S. Umnyakova ${ }^{1}$, V.N. Kokryakov ${ }^{1,2}$ \\ ${ }^{1}$ Institute of Experimental Medicine, Saint Petersburg, Russia; \\ ${ }^{2}$ Saint Petersburg State University, Saint Petersburg, Russia
}

\section{АНТИМИКРОБНАЯ АКТИВНОСТЬ ЛИЗОЦИМА В ОТНОШЕНИИ LISTERIA MONOCYTOGENES В РАЗЛИЧНЫХ УСЛОВИЯХ СРЕДЫ}

\author{
М.Н. Берлов ${ }^{1}$, С.В. Легковой ${ }^{2}$ Е.С. Умнякова ${ }^{1}$, В.Н. Кокряков ${ }^{1,2}$ \\ ${ }^{1}$ ФГБНУ «Институт экспериментальной медицины», Санкт-Петербург; \\ ${ }^{2}$ Санкт-Петербургский государственный университет, Санкт-Петербург
}

\begin{abstract}
Исследовалось антимикробное действие in vitro лизоцима из лейкоцитов человека на грамположительную бактерию Listeria monocytogenes в различных условиях среды. Показано, что в буфере с низкой ионной силой (без $\mathrm{NaCl}$ ) требуются на порядок меньшие дозы лизоцима для проявления микробоцидного эффекта, чем в присутствии 0,075 или $0,15 \mathrm{M} \mathrm{NaCl}$. Фаза роста бактериальной культуры не оказывает существенного влияния на антимикробную активность лизоцима. Полученные результаты согласуются с двухстадийным механизмом антимикробного действия лизоцима, включающим ферментативное и неферментативное действие.
\end{abstract}

Ключевые слова: лизоцим; антимикробная активность; Listeria monocytogenes.

The in vitro antimicrobial action of human leukocyte lysozyme from on gram-positive bacterium Listeria monocytogenes under various medium conditions was studied. It was shown that in a low ionic strength buffer (without $\mathrm{NaCl}$ ), lower doses of lysozyme are required to reveal the microbicidal effect than in the case of 0.075 or $0.15 \mathrm{M} \mathrm{NaCl}$. The bacterial growth phase does not significantly affect the antimicrobial activity of lysozyme. The results obtained are consistent with the two-stage mechanism of the antimicrobial action of lysozyme, which includes enzymatic and non-enzymatic action.

Keywords: lysozyme; antimicrobial activity; Listeria monocytogenes.

Introduction. Though lysozyme $(\mathrm{Lz})$ as an antimicrobial protein is studied about a century, its specific contribution to human defense against infection is far from clear. Lz is an enzyme which hydrolyzes glycoside bonds in the bacterial peptidoglycan thus destroying the cell wall. Gramnegative bacteria are usually resistant to $\mathrm{Lz}$ since their peptidoglycan is protected by the outer membrane. Moreover, it is generally accepted that under physiological conditions, most gram-positive bacteria also survive under $\mathrm{Lz}$ action as protoplasts, but at hypotonic conditions, they are lysed as a result of osmotic shock. On the other hand, some authors consider $\mathrm{Lz}$ as the main bactericidal factor of human plasma for gram-positive bacteria [1]. In addition, there are some data indicating that enzymatic activity of $\mathrm{Lz}$ is not essential for its antimicrobial properties, instead, it could function as a membrane-active cationic protein similar to antimicrobial peptides such as defensins [2;3].

In spite of the simplicity of this idea, we could not find in literature direct comparison of antimicrobial (not just enzymatic) activity of $\mathrm{Lz}$ at different ionic strength.

The aim of this study was to investigate an antimicrobial activity of Lz towards gram-positive bacterium Listeria monocytogenes at various medium conditions. Three concentrations of $\mathrm{NaCl}$ were selected for these experiments, namely
$150 \mathrm{mM}$ for mimicking physiological conditions; $75 \mathrm{mM}$ for optimal enzymatic activity of Lz [4]; and $0 \mathrm{mM}$ (NaCl-free buffer) for optimal osmotic lysis. In addition, we tested the influence of buffer nature (phosphate or veronal) and growth phase of bacterial culture on the antimicrobial activity of Lz.

Material and methods. Lysozyme was isolated from human leukocytes by their freezing-thawing destruction and protein fractionation by consecutive cation-exchange chromatography on CMcellulose and gel filtration on G-75. The purified protein revealed a typical for $\mathrm{Lz}$ capacity to lyse lyophilized cell walls of Micrococcus lysodeikticus.

Antimicrobial activity towards Listeria monocytogenes EGD was evaluated by a colony counting assay as described previously [5]. $10 \mathrm{mM}$ buffer solutions with $\mathrm{pH} 7.4$ were used in these experiments. If not specified otherwise, bacterial cells in the exponential growth phase were taken for antimicrobial tests. Minimum inhibitory concentration was determined as a minimum dose of Lz leading to at least a one order of magnitude decrease in the number of bacterial colonies compared with the control.

Results and discussion. We found that ionic strength dramatically affects the antimicrobial activity of Lz (see Table). However, the inhibitory effect of $\mathrm{NaCl}$ can be overcome by increasing the $\mathrm{Lz}$ concentration. In addition, $\mathrm{Lz}$ is more active in the veronal buffer than in the phosphate buffer. 
Minimum inhibitory concentration of $\mathrm{Lz}(\mu \mathrm{g} / \mathrm{ml})$ against $L$. monocytogenes

\begin{tabular}{|l|c|c|c|}
\hline & Phosphate buffer & Veronal buffer & Veronal buffer, stationary phase \\
\hline Without NaCl & 2 & 0.5 & 1 \\
\hline $0.075 \mathrm{M} \mathrm{NaCl}$ & 32 & ND & ND \\
\hline $0.15 \mathrm{M} \mathrm{NaCl}$ & 64 & 64 & ND \\
\hline
\end{tabular}

Note. ND - not determined.

It seems that the antimicrobial action of $\mathrm{Lz}$ involves two stages: enzymatic lysis of the cell wall peptidoglycan and non-enzymatic disruption of the cytoplasmic membrane. The latter requires more than an order of magnitude higher Lz doses. Under hypotonic conditions, the second step probably is not essential since membrane lysis is achieved by osmotic force. In addition, lower doses of Lz would be effective in the second step in $\mathrm{NaCl}$-free buffer because it is expected to be salt-sensitive as described for defensins. It is known that defensins are much more active towards bacteria in the exponential growth phase compared with the stationary phase. However, we did not observe a remarkable difference in the case of Lz as an antimicrobial agent. Presumably, it is easier for defensins to gain access to the cytoplasmic membrane of dividing bacterial cells, but it is not important for $\mathrm{Lz}$, which provide access to the membrane by its own enzymatic action on peptidoglycan.

Conclusion. Our results imply that Lz alone can exhibit an antimicrobial effect on some grampositive bacteria such as $L$. monocytogenes or equally sensitive in human saliva, tears or milk. On the other hand, in the blood plasma Lz level is insufficient to kill bacteria at physiological ionic strength. However, plasma Lz can convert bacterial cells to protoplasts making them susceptible to other bactericidal factors such as complement or antimicrobial peptides. This assumption is partially confirmed by literature data [6].

\section{References}

1. Selsted ME, Martinez RJ. Lysozyme: primary bactericidin in human plasma serum active against Bacillus subtilus. Infect. Immun. 1978;20:782-791.

2. Düring K, Porsch P, Mahn A, et al. The non-enzymatic microbicidal activity of lysozymes. FEBS Lett. 1999;449:93-100.

3. Ibrahim HR, Matsuzaki T, Aoki T. Genetic evidence that antibacterial activity of lysozyme is independent of its catalytic function. FEBS Lett. 2001;506:27-32.

4. Davies RC, Neuberger A, Wilson BM. The dependence of lysozyme activity on $\mathrm{pH}$ and ionic strength. Biochim. Biophys. Acta. 1969;178:294-305.

5. Berlov MN, Korableva ES, Andreeva YV, et al. Lactoferrin from canine neutrophils: isolation and physicochemical and antimicrobial properties. Biochemistry (Moscow). 2007;72:445-451.

6. Muschel LH, Jackson JE. The reactivity of serum against protoplasts and spheroplasts. J. Immunol. 1966;97:46-51. 